\title{
INTERNATIONAL COMPETITIVENESS OF ASEAN REGIONAL INTEGRATION
}

\begin{abstract}
Purpose: In addition to being one of the major regional integrations, owing to its favorable geopolitical position, demographic indicators, and economic power, the Association of Southeast Asian Nations (ASEAN) is also one of the world's largest and most influential economic superpowers. This paper aims to examine the international competitiveness and trade of ASEAN member states.

Methodology: The research methodology is based on the use of a group of indicators of trade balance, intra-industry trade, the share of exports in imports, trade openness, and the share of exports in GDP in the period from 2013 to 2017.

Results: The main results of the paper refer to the evaluation of the competitive position of ASEAN member states' in international terms (Indonesia, Malaysia, Philippines, Singapore, Thailand, Brunei Darussalam, Vietnam, Laos, Myanmar, and Cambodia), as well as to the aggregated results of ASEAN regional integration indicators.
\end{abstract}

Conclusion: The paper's concluding remarks are an attempt to determine the trading position of ASEAN member states and provide recommendations on how to enhance their international competitiveness.

Keywords: ASEAN, international competitiveness, international trade, regional integration

\section{Introduction}

The Association of Southeast Asian Nations (ASEAN) was established on 8 August 1967 in Bangkok. The founding countries were Indonesia, Malaysia, the Philippines, Singapore, and Thailand. Brunei Darussalam joined ASEAN in 1984, followed by Vietnam in 1995, Laos and Myanmar in 1997, and finally Cambodia in 1999. In 2019, they were considered the fastest growing economies in Southeast Asia that foster continuous economic and political cooperation.

In 2008, the ASEAN regional integration had a population of 649.1 million and ranked as the fifthlargest economy in the world, with a GDP of ap- proximately US $\$ 3$ billion. GDP per capita recorded exponential growth (US\$ 4,601.3 in 2018), which was up to 4 times higher than in 2000. From 2005 to 2018, in the total economy of ASEAN, the tertiary sector dominated with a share of $50 \%$, followed by the secondary sector (manufacturing industry) with $37 \%$, and the primary sector (agriculture) with a $10 \%$ share. In 2018, the greatest ASEAN exports were realized within the 10 member states' borders, followed by China, the EU28, the USA, and Japan. An identical situation is characteristic of the ASEAN import activities (ASEAN, 2019). The ASEAN's importance to the European Union is evident from various ministerial meetings, where a number of issues have been considered and discussed. Some of them are the need for strengthening mutual rela- 
tions, promoting EU-ASEAN connectivity, enhancing political and security cooperation, addressing climate change and the environment, protection of human rights and fundamental freedoms, as well as some of key challenges facing Europe, Southeast Asia, and the world (European Council, 2019).

The main objectives and purpose of establishing ASEAN were to support and accelerate economic growth, social progress, and cultural development of the region, as well as to promote regional peace and stability by respecting the laws and rules set by each country. As an additional pillar in achieving these objectives, the ASEAN Free Trade Area (AFTA) was established in 1992. The fundamental goal of AFTA is to promote the region's competitive advantage as a single production base by removing tariffs and non-tariff barriers between member states. The target date for achieving the complete abolition of import duties on all goods was 2015 for the initial six ASEAN member states and 2018 for the newer members. The abolition of import duties has enhanced ASEAN's domestic and international competitiveness (Bilas \& Franc, 2009).

ASEAN member states act according to the fundamental principles such as mutual respect for the independence, sovereignty, equality, territorial integrity, and national identity of all nations. Each member state has the right to pursue its own policy free from external interference, subversion or coercion. Potential disagreements and disputes are resolved amicably, and the use of any kind of force is not allowed. Ultimately, all member states agreed to establish and foster effective cooperation ${ }^{1}$. The vision of ASEAN is to create a stable, prosperous, and competitive region with free movement of goods, services and investment, free flow of capital, equitable economic growth, and reduced poverty and socio-economic disparities.

This paper's main scientific hypothesis proposes that by conducting a structural analysis of international trade indicators, it is possible to assess the current level of international competitiveness of ASEAN member states. The principal objective of this research is to measure and evaluate the international competitiveness of ten ASEAN member states and, based on the results, propose measures and activities to improve their position.

The paper consists of four systematically connected parts. Following the introduction, the second part of the paper presents previous research on the topic of competitiveness, international competitiveness,

1 Association of Southeast Asian Nations (2019). www.aseansec.org and the ASEAN organization. In the third part, the research methodology is presented. The fourth part of the paper includes the results of international competitiveness obtained by applying international trade indicators. The final section of the paper contains recommendations and proposals, as well as concluding remarks.

\section{Previous research}

The Organisation for Economic Co-operation and Development (OECD) and the Department of Trade and Industry (DTI) highlight the importance of technological factors in creating competitiveness. DTI (1994) defines company competitiveness as the ability to produce the right products and services at the right time and at the right price. The OECD's definition (OECD, 1992), from a micro perspective, perceives competitiveness as the company's ability to compete, maximize profits, and achieve growth based on costs and prices by using technology, improving quality, and maximizing the performance of its products.

There are a number of researchers who have been exploring the relationship between competitiveness and technological capabilities. Some of them, e.g. Edwards and Fagerberg (2001), Kaldor (1971), Porter (2001), Lall (2001), and Wignaraja (2003), as well as some institutions, such as the OECD, have opposed the views of researchers who define competitiveness only in terms of price-based factors, while emphasizing the non-price factors, such as technology. The discussion led to a revision of traditional theories of competitiveness.

In general, two different aspects that look at the concept of competitiveness stand out. The general macroeconomic aspect portrays international competitiveness in terms of price-based factors. In contrast, the microeconomic aspect seeks to define competitiveness at the company level with nonprice-based factors, where the emphasis is put on researching competition between companies.

The macroeconomic perspective is concerned with the internal and external balance of economies and focuses on the impact of price-based factors on the competition. This perspective looks at the internal dynamics of a company, which makes the company more or less susceptible to influences (Wignaraja, 2003).

The microeconomic aspect shows competitiveness at the company level. The perspective includes the rivalry between companies and their strategies. In 
the last few decades, the microeconomic aspect has taken on new dimensions, such as the impact of technology and innovation. Lall (2001) revises the neoclassical theory, which is based on the thesis that technology is available to all companies that have the capability to apply advanced technology. However, this is a long-term learning process that begins with the import of technology and continues with the innovations (Galović, 2015).

As a highly popular topic in scientific circles, international competitiveness has been studied from different angles (Krugman, 1994; De Grauwe, 2010). In other words, international competitiveness is a very comprehensive concept that can be examined at different levels: production, industrial or sectoral, regional, state, trade bloc, or as an aspect of global trade. Moreover, there is a close link between different levels of competitiveness (Anca, 2008). It is a concept examined not only from an economic point of view but also from a historical, political, and cultural aspect. Even in economics, international competitiveness is associated with different theoretical approaches, i.e., classical and neoclassical Keynesian theories, development economics, new growth theory, and modern trade theory.

In scientific literature, international competitiveness is often equated with exports; yet, there are differing perspectives among researchers. Krugman (1994) argues that imports are one of the essential principles of international trade, while exports are beneficial for allowing the product profit and necessary acquisition of cheaper and better foreign products. Without considering Krugman's perspective, Meiliene \& Snieska (2010), Saboniene (2009), and Armstrong \& Taylor (2005) tend to prove the importance of exports in the country's competitiveness. They argue that competitiveness is related to the increase in the economy's exports (which is not related to the increase in imports) that allows activities to expand to foreign markets, resulting in increased revenues and diversified export structure.

In literature, there are several generally accepted definitions by scholars who have examined the topic of international competitiveness. The fact is that international competitiveness is derived from the competition (Porter, 1990). Moreover, numerous researchers have defined competitiveness as a relative and multidimensional concept (Spence \& Hazard, 1988; Flanagan et al., 2007) that is usually regarded as a synonym for success and economic power in the global environment (Srivastava et al., 2006). Some economists also agree that the origins of internation- al studies on competitiveness can be found in classical theories of international trade (Olczyk, 2016).

Numerous papers on the (international) competitiveness of the ASEAN regional integration have been written. Namely, Nyusheva et al. (2018) consider the challenges faced by ASEAN. The authors present the advantages and disadvantages of regional integration of each ASEAN member state for the period from 2008 to 2017. They point out that, through the prism of cultural differences, competitiveness, etc., there are noticeable differences between member states. Nababan (2019) examines the Global Competitiveness Index (GCI), progress factors, as well as the impact of GDP on GCI for seven selected ASEAN member states. The conclusion is that the GDP of those seven ASEAN countries has a positive and significant impact on the GCI, except for Thailand. The author concludes that corruption, access to financing, tax regulations, and government inefficiency are the most significant obstacles to the competitiveness of ASEAN member states. Fan and Chang (2010) explore the international competitiveness of the service sector of China and ASEAN countries on the basis of their export market share, trade competitiveness, and RCA index. The authors come up with proposals for the improvement of the service sector of China and ASEAN. Loo (2018) explores the global competitiveness of ASEAN and its implications for Canadian businesses focusing on 12 industrial areas. The results indicate four ASEAN market segments where Canadian companies could offer their products and services (Cambodia, Laos, Myanmar, and Vietnam).

\section{Methodology}

The analytical approach is based on the application of indicators measuring the international competitiveness of 10 member states (Indonesia, Malaysia, the Philippines, Singapore, Thailand, Brunei Darussalam, Vietnam, Laos, Myanmar, and Cambodia) and the ASEAN regional integration as a whole. The observed period is from 2013 to 2017. In order to successfully measure the international competitiveness and trade of ASEAN member states, the indicators of intra-industry trade (IITR), export-import ratio (EXIM), trade openness index (TOI), share of exports in GDP (EGDP), and trade balance (TBAL) are used. The indicators were applied to measure the advantages and limitations of the economy's international trade flows. In other words, these indicators suggest the level of trade specialization and competitiveness in foreign markets (Bezić \& Galović, 2013; Bezić \& Galović, 2014). The main 
objective of the methodology is to show the changes in the trade flows of the ASEAN regional integration. Besides the primary indicators, the indicators used in the OECD statistical database $(2020)^{2}$ are also applied in this paper.

Analyses of industrialization and economic growth factors highlight the importance of intra-industry trade $^{3}$ (World Bank, 2014). Intra-industry trade brings additional benefits in international trade as well as comparative advantages due to the access to larger markets.

The indicator that measures the intra-industry trade was initially created by Balassa, describing it as the degree to which the export value of an industry coincides with the value of its imports (Balassa, 1966). IITR indicator, according to Balassa, represents the unweighted average of the trade deficit in the country's total international trade and measured inter-industry trade. The main disadvantage of this indicator is related to the equal importance of all industries regardless of their share in trade, and the disregard for trade imbalance. Based on Balassa's research, Grubel and Lloyd (1975) continued developing this intra-industry trade model.

Intra-industry trade (IITR) represents the value of total trade that remains after deducting the absolute value of net exports or imports. To compare the countries, the measures are expressed as a percentage of exports and imports of each ASEAN member state. According to the OECD statistical database (2020), the intra-industry trade indicator is calculated as follows:

$\operatorname{IITR}_{i}=\left(1-\frac{\left|\operatorname{expo}_{i}-i m p o_{i}\right|}{\operatorname{expo}_{i}+\operatorname{impo}_{i}}\right) \times 100$

where:

expo $_{i}$ - exports of the country "i"

impo $_{i}$ - imports of the country "i"

The results of the indicators vary between 0 and 100. If a country exports and imports approximately equal the quantities of a particular product, the value of the index is high. If the trade is mostly one-way (either exported or imported), the index value is low.

The export-import ratio (EXIM) shows the share of exports in imports of the observed ASEAN member state. Values greater than 1 indicate a positive trade balance, while values less than 1 indicate a negative trade balance (Eurostat, 2020). The equa-

2 OECD Statistics (2020). http://stats.oecd.org

3 World Bank (2014). https://data.worldbank.org tion of the ratio of exports and imports is shown as follows:

$$
\operatorname{EXIM}_{i}=\frac{\operatorname{expo}_{i}}{\operatorname{impo}_{i}} \times 100
$$

where:

expo $_{i}$ - exports of the country "i"

impo $_{i}$ - imports of the country "i"

The ratio shows whether a country exports more than it imports, or vice versa. Apart from providing insight into the state of trade balance (exports imports), the indicator's advantage is the countries' comparison.

Trade openness brings numerous economic benefits, including the increased transfer of technology, knowledge, and skills, increased labor and total factor productivity, as well as economic growth and development. The trade openness index (TOI) measures the openness of the economy. It is calculated as the sum of the values of realized exports and imports in relation to the realized gross domestic product of the observed country in a given period. The equation is shown below:

$$
\mathrm{TOI}_{i}=\frac{\operatorname{expo}_{i}+\operatorname{impo}_{i}}{G D P_{i}}
$$

where:

expo $_{i}$ - exports of the country "i"

impo $_{i}$ - imports of the country "i"

$G D P_{i}$ - gross domestic product of the country " $i$ "

The share of exports in GDP (EGDP) or the indicator of export propensity is shown below. The export propensity indicator shows the overall degree of reliance of domestic producers on foreign markets (UNCTAD, 2020). When measuring the export propensity indicator of a particular country, the following elements of the equation are taken into account:

$$
E G D P_{i}=\frac{\operatorname{expo}}{G D}_{i}
$$

where:

$$
\begin{aligned}
& \text { expo }_{i} \text { - exports of the country "i" } \\
& \text { impo }_{i} \text { - imports of the country "i" } \\
& G D P_{i} \text { - gross domestic product of the country " } i \text { " }
\end{aligned}
$$

The increasing share of exports in the gross domestic product indicates a higher export propensity. In contrast, the decreasing share of exports in the 
GDP of the observed ASEAN country points to a lower degree of export propensity.

The trade balance indicator (TBAL) can be interpreted as the difference between export and import activities of the observed country. A positive result (exports are higher than imports) suggests a trade surplus, while a negative result (imports are higher than exports) indicates a trade deficit of the observed country. It is calculated as follows:

$T B A L_{\mathrm{i}}=\operatorname{expo}_{i}-$ impo $_{i}$

where:

expo $_{i}$ - exports of the country "i"

impo $_{i}$ - imports of the country "i"

The presented indicators are used to measure the international competitiveness of ASEAN mem- ber states. The results of the applied methodology framework are presented in the following paragraph.

\section{Results}

The analysis begins with measuring the international competitiveness based on the example of ten member states (Indonesia, Malaysia, the Philippines, Singapore, Thailand, Brunei Darussalam, Vietnam, Laos, Myanmar, and Cambodia) and the aggregated category of ASEAN. The observed period is from 2013 to 2017. The results of the analysis relate to the application of the intra-industry trade (IITR), export-import ratio (EXIM), trade openness index (TOI), share of exports in GDP (EGDP), and trade balance (TBAL) indicators. Figure 1 shows the intra-industry trade of ten ASEAN member states in the period from 2013 to 2017.

\section{Figure 1 Intra-industry trade of ASEAN (IITR)}

150

130

110

.

70

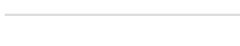

(n)

50

50

30
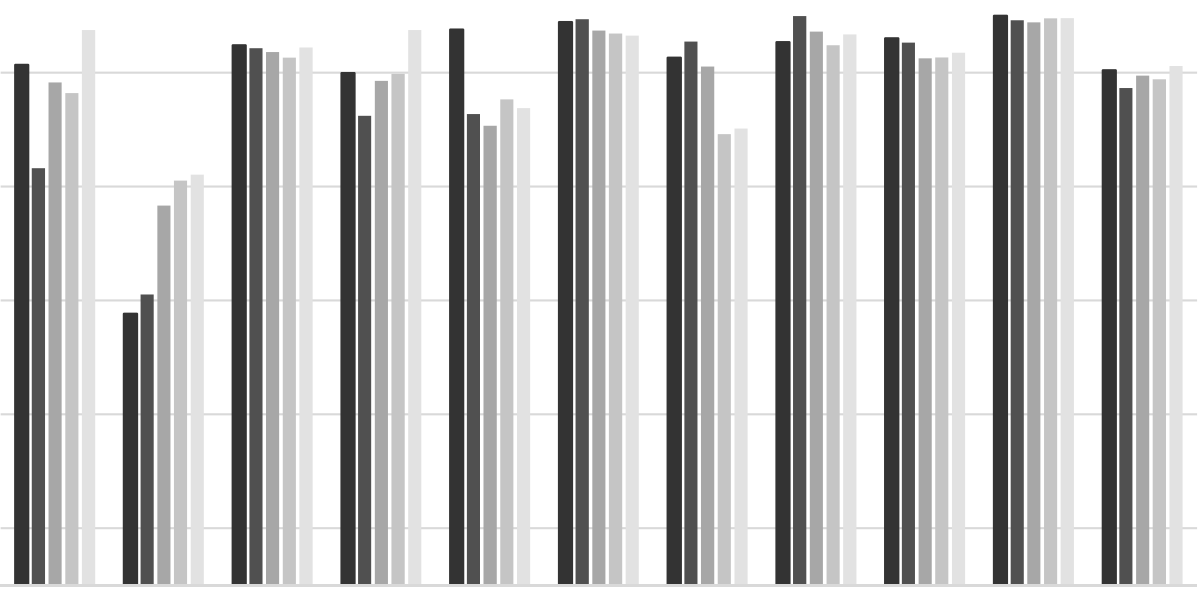

$-10$

Laos

Brunei

Malaysia Cambodia Myanmar Indonesia Philippines Thailand Singapore Vietnam

ASEAN

$\square 2013 \square 2014 \square 2015 \square 2016 \square 2017$

Source: Author's processing according to https://www.aseanstats.org (2020) ${ }^{4}$

4 ASEAN Stats 2020. https://www.aseanstats.org 
From the results, it can be concluded that all observed ASEAN states have similar values of the intra-industry trade indicator. In other words, almost all member states except Brunei have recorded values of around 100. The results indicate the two-way trade, where imports and exports are roughly equal. In contrast, Brunei, with a lower value of the IITR indicator, is a country with one-way trade. More precisely, it has recorded more intensive exports, as evident from the realized trade surplus. Brunei's most significant exports include a group of products such as liquefied natural gas, petroleum oils, and methanol.

ASEAN's aggregated analysis can confirm the volatile trend of the intra-industry trade indicator in the observed period. The lowest value was recorded in 2014, and the highest in 2017.

Figure 2 illustrates the share of exports in imports of ASEAN member states for the period from 2013 to 2017.

\section{Figure 2 Export-import ratio of ASEAN (EXIM)}

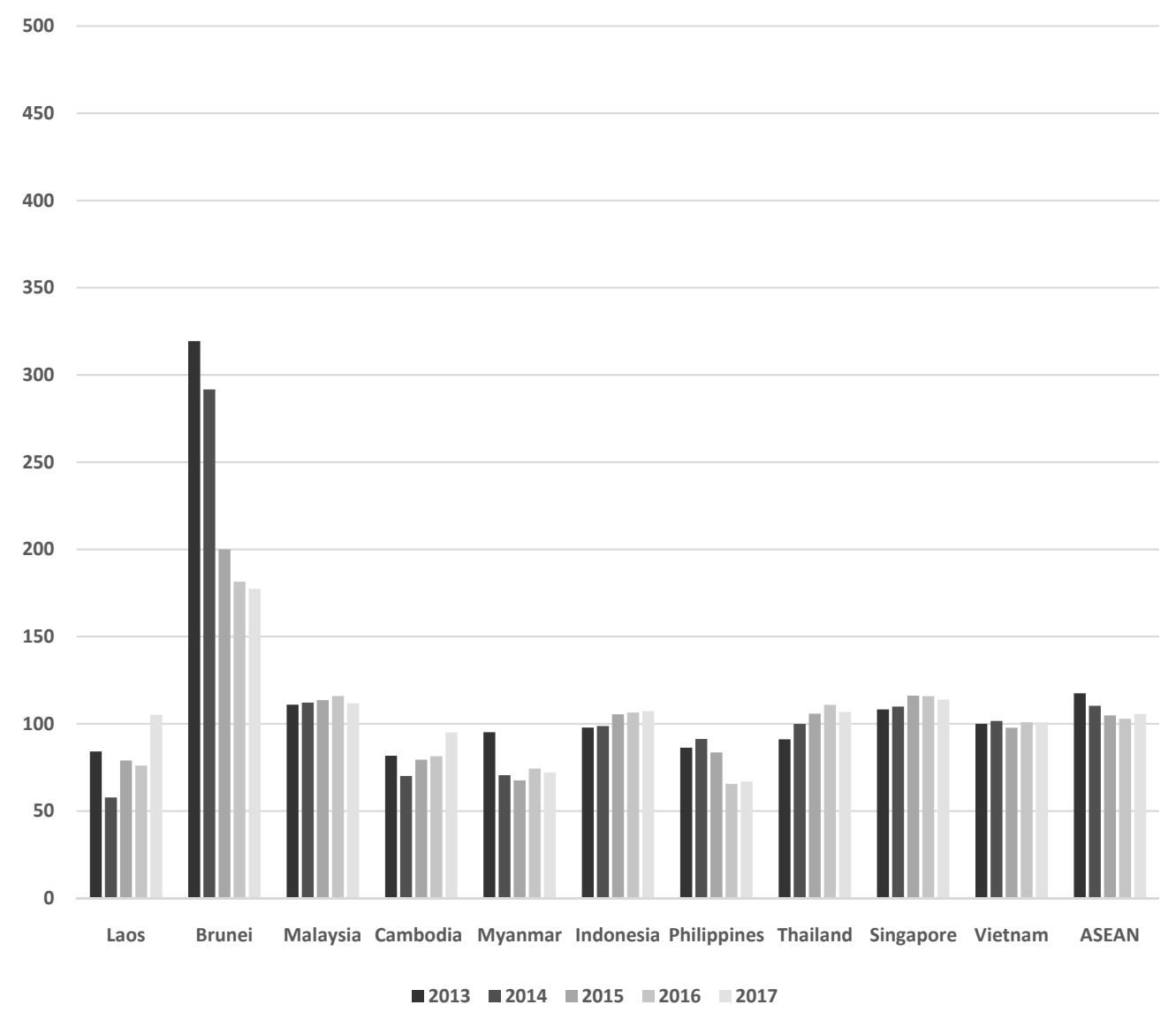

Source: Author's processing according to https://www.aseanstats.org (2020)

Of all ASEAN member states, Brunei's export activity significantly exceeds its imports. This is due to the small absorption power of the market (around 430,000 inhabitants), while the world's demand for export products is far higher. However, the indicator of the share of exports in Brunei imports recorded a downward trend over the observed period. Exports exceed imports in Malaysia, Singapore, and Thailand as well. These export-oriented countries with a trade surplus are above the average of the ASEAN regional integration in terms of the share of exports in imports. In 2017, the lowest value of the EXIM indicator could be seen in the Philip- 
pines and Myanmar. Although the Philippines ranked $37^{\text {th }}$ largest export economy in the world, it has faced a trade deficit as exports made up $2 / 3$ of imports. The share of exports in Myanmar's imports is approximate- ly $72 \%$, which confirms that Myanmar is one of the largest importer among ASEAN countries. Figure 3 shows the ASEAN trade openness indicator for the reference period from 2013 to 2017.

\section{Figure 3 Trade openness indicator of ASEAN (TOI)}

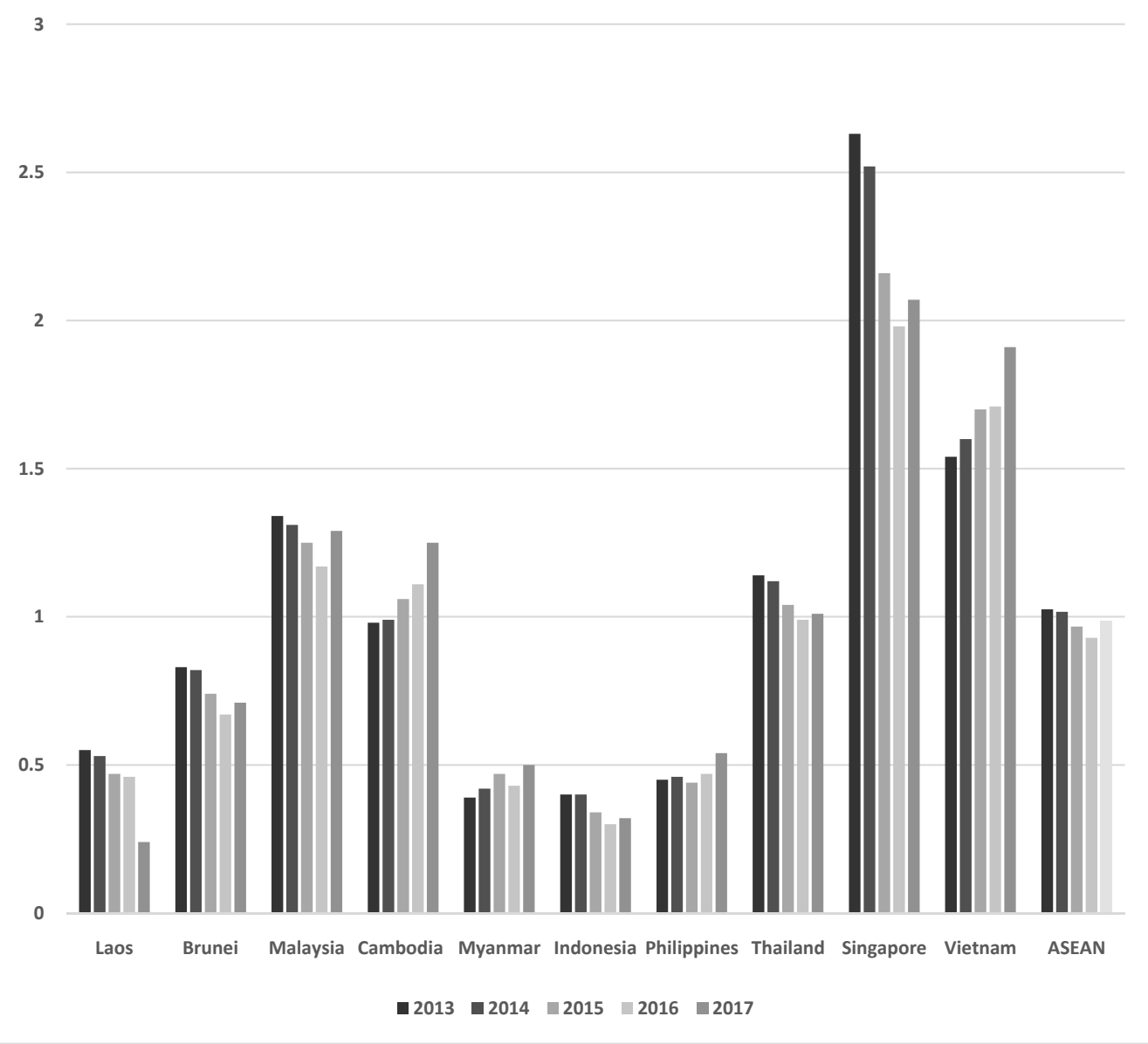

Source: Author's processing according to https://www.aseanstats.org (2020)

The highest level of trade openness can be observed in countries such as Singapore, Vietnam, Malaysia, and Cambodia. Their TOI indicator is higher than 1 , which implies the international trade connectivity, that is, the interdependence with the rest of the world. Generally, these countries are the exportoriented, except for Cambodia. The lowest trade openness is recorded in the case of the Philippines, Myanmar, and Laos. TOI values for these countries range between 0 and 0.55 . The TOI indicator results for the ASEAN integration range between 0.93 and 1 , indicating a relatively high degree of trade openness. The downward trend of the TOI indicator is evident in the observed period, except for 2017. In 2017, the positive change of the TOI was caused by increased growth in exports (chain index 15\%) and imports (chain index \$13), compared to the GDP of the ASEAN organization (chain index 7\%). Figure 4 shows the level of export propensity of ASEAN member states. 
Figure 4 Share of exports in GDP of ASEAN countries (EGDP)

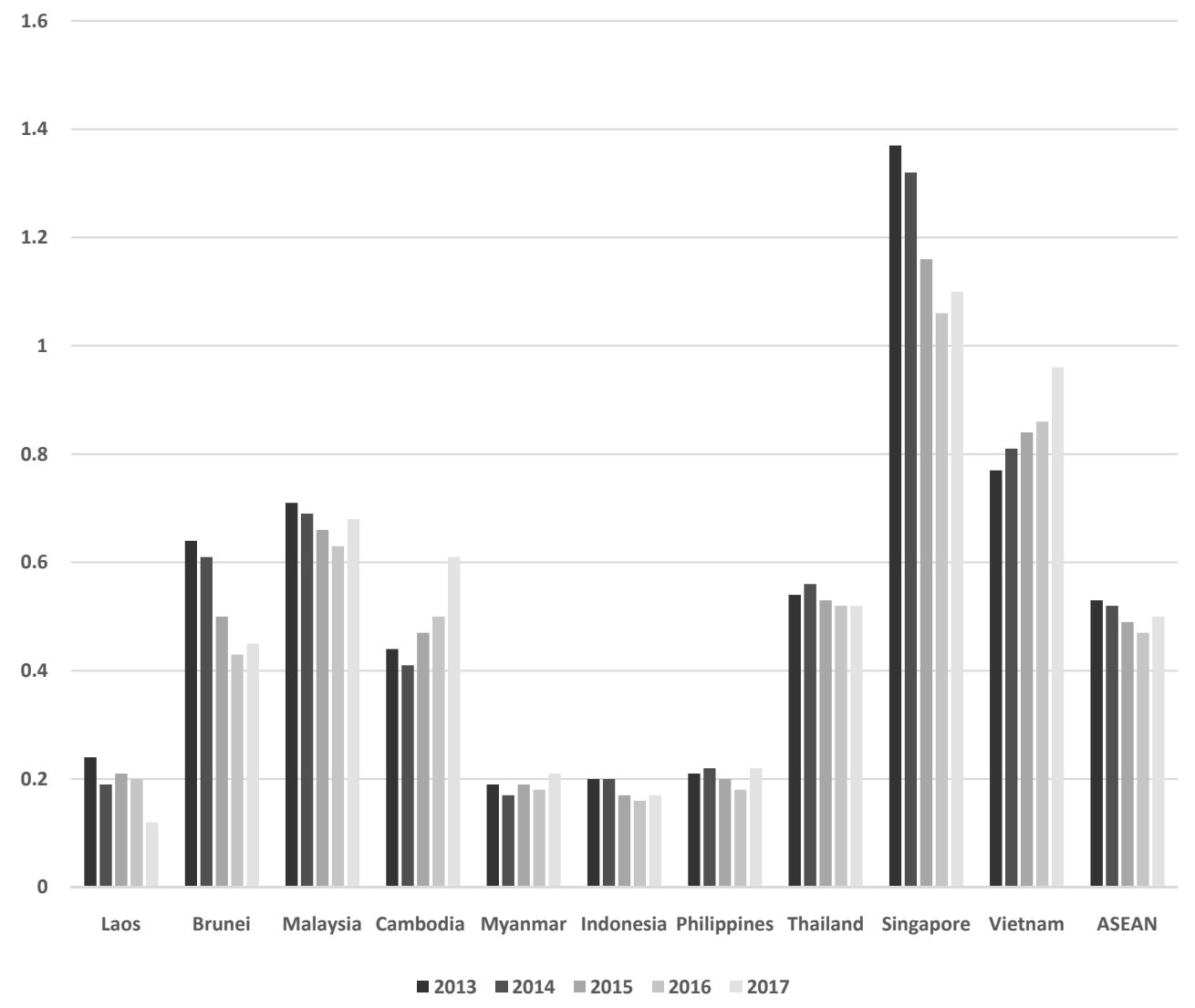

Source: Author's processing according to https://www.aseanstats.org (2020)

Stronger export propensity is observed for Singapore, Vietnam, and Malaysia. Their EGDP indicator values exceed the ASEAN integration value. In the previous figures, it was assumed that these countries were export oriented, which is confirmed by data presented in Figure 4. Singapore mostly exports integrated electronic circuits, refined petroleum, and gold, Vietnam exports mainly broadcasting equipment, telephones, and integrated electronic circuits, while Malaysia exports integrated electronic circuits, refined petroleum, and parts of office equipment. The smallest share of exports in GDP is characteristic of the Philippines, Indonesia, and Myanmar, whose EGDP indicators are twice as low as the ASEAN's average. Clearly, these countries are import oriented. It should be noted that the results presented in previous Figures are associated with the results presented in the Figure 5, which shows the trade balance of the regional organization of ASEAN and its member states for the period from 2013 to 2017. 
Figure 5 Trade balance indicator of ASEAN (TBAL)

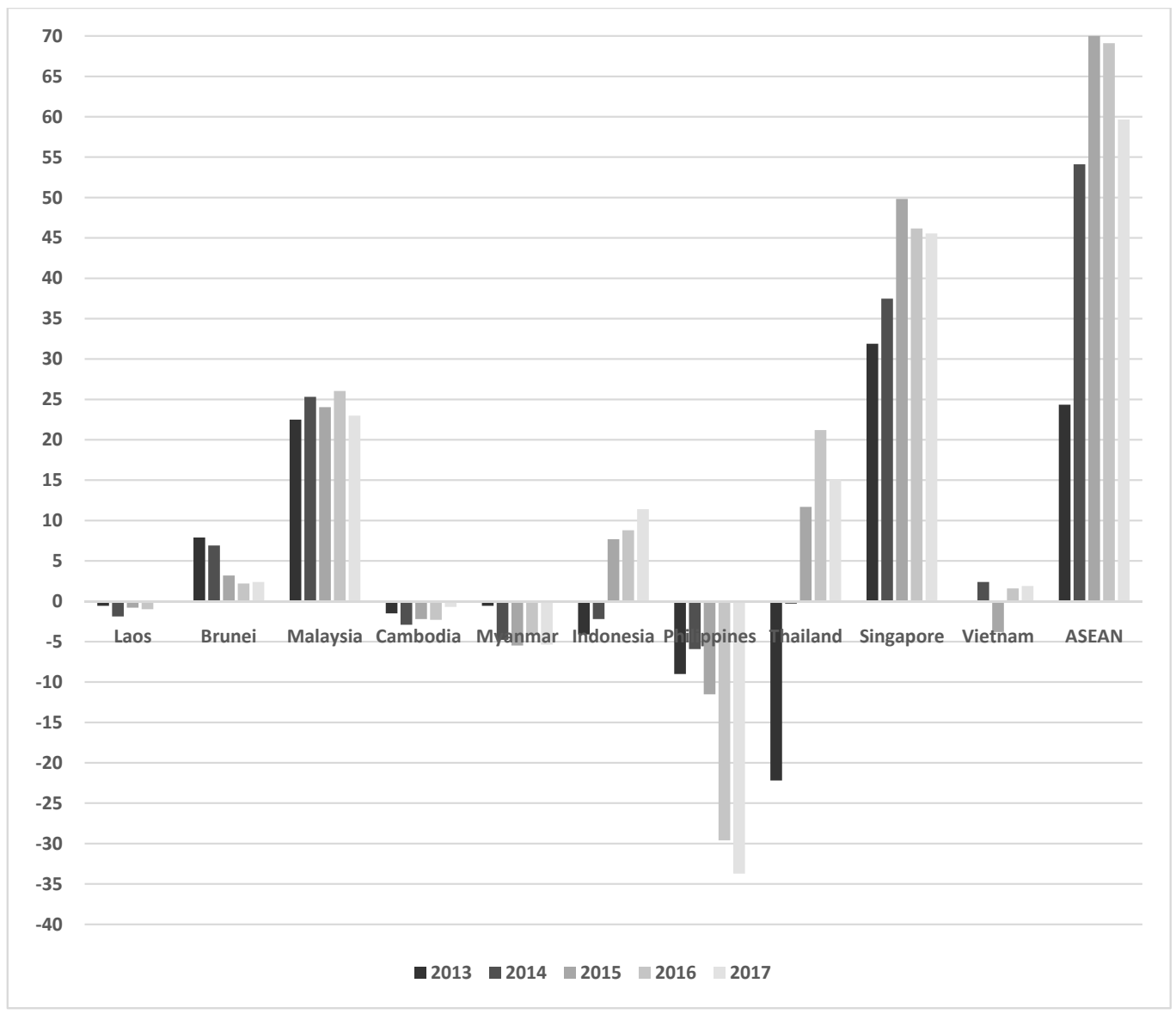

Source: Author's processing according to https://www.aseanstats.org (2020)

The data presented in Figure 5 additionally confirm the international competitiveness of ASEAN member states. The trade surplus was recorded in Singapore, Thailand, Malaysia, and partially in Indonesia and Vietnam. The trade surplus of countries is lower than the aggregated trade balance of ASEAN. The TBAL indicator complements the values of EGDP, TOI, EXIM, and IITR indicators for Singapore, Thailand, and Malaysia. The results suggest that these three member states have the highest level of international competitiveness. In contrast, Laos, Cambodia, Myanmar, and the Philippines recorded a trade deficit in the observed period. The Philippines had the most pronounced trade deficit, which suggests a high level of import dependence. The Philippines imports mostly from China, Japan, and South Korea. Integrated electronic circuits, refined petroleum, and vehicles accounted for the majority of the imports. Laos, Cambodia, and Myanmar recorded a much smaller trade deficit, as evident from higher imports than exports. In general, ASEAN is marked by a volatile trend of trade surplus, which was at its highest in 2015. Over the entire period, this regional organization had higher exports than imports, and the highest trade was realized in 2017.

\section{Discussion}

ASEAN has become a powerful regional economic integration mainly owing to developed countries such as Singapore, Indonesia, Malaysia, and Thai- 
land. Their advantages are reflected in the high contribution to the GDP, export propulsiveness, trade surplus, i.e., a high level of international competitiveness. In other words, these are the leading ASEAN member states with representative trade openness. Singapore, Malaysia, and Thailand are dependent on supply chains, which can reduce market demand. The final result could be the need for restructuring. The economy of Thailand is highly dependent on the tourism sector and could be most at risk compared to other member states. Indonesia and the Philippines also play an important role in the regional supply chains and will not be spared from the negative effects of the COVID-19 pandemic.

The international competitiveness of countries like the Philippines, Myanmar, and Laos is characterized by a high trade deficit and a high level of import dependence. The economy of ASEAN countries was brought to a standstill by the COVID-19 crisis. The coronavirus pandemic (COVID-19) has upended the economy of the ASEAN organization bringing steep economic challenges. In particular, the sectors of tourism and transport have been negatively affected. Disruptions in the supply chain and labor market were noticed, which had severe repercussions for the ASEAN trade, investment activity, and production. There is a shadow over future prospects of the ASEAN economy, which will significantly affect the international competitiveness of its member states. However, the advantage of ASEAN can be drawn from the adaptation, that is, reallocation of particular supply chain activities from China to the ASEAN organization. While this may present certain economic challenges for ASEAN member states during the reallocation phase, some of them may benefit from new investments and thus mitigate the overall negative impacts of the COVID-19 situation.

\section{Conclusion}

ASEAN is a regional integration that fosters economic, political, and security cooperation among its ten member states: Brunei, Cambodia, Indonesia, Laos, Malaysia, Myanmar, the Philippines, Singapore, Thailand, and Vietnam. In other words, ASEAN represents the integration of countries of different development levels that find interest in mutual integration. Moreover, as a trade bloc, the
Association has been characterized by stability, security, and progress in Southeast Asia. The organization, as a whole, is constantly evolving and striving to improve its international competitiveness. To achieve a competitive position, ASEAN regional integration is taking a number of measures to enhance homogeneity across its members. One of ASEAN's challenges is the uneven economic growth of individual member states.

The research results confirm the main scientific hypothesis proposing that by conducting a structural analysis of foreign trade indicators, it is possible to assess the current level of international competitiveness of ASEAN member states. Some interesting findings are obtained by aggregating the results of the calculated indicators for ten ASEAN member states. Considering the period from 2013 to 2017, ASEAN member states could be divided into exporting countries and countries with a high level of import reliance. The applied indicators of international competitiveness clearly indicate the dominant positions of Singapore, Malaysia, Vietnam, and Brunei, while there is room for improvement for the Philippines, Laos, and Myanmar.

An analysis of the aggregate average values for ASEAN reveals a satisfactory level of international competitiveness. A predominantly downward trend marks the trade openness, export-import ratio, and the share of exports in the GDP of ASEAN. The exception is 2017, during which almost all indicators of international competitiveness used in this study increased. It should be emphasized that the Association has recorded a trade surplus, which confirms the export orientation of this trading bloc. The exception is 2017, when a decline in the trade surplus was recorded, which remained positive.

The research results lead to the conclusion that this regional integration is still facing structural challenges, as well as one unavoidable negative factor, the COVID-19 crisis. This crisis will have severe consequences for the international competitiveness of the ASEAN organization and its international trade partners.

\section{Acknowledgment}

The paper was financially supported by the University of Rijeka, under the project number uniridrustv-18-16. 


\section{REFERENCES}

1. Anca, H. (2008). Literature review of the evolution of competitiveness concept. http://steconomiceuoradea.ro/anale/volume/2012/n1/004.pdf

2. Armstrong, H. \& Taylor, J. (2004). Regional Economics and Policy. Blackwell Publishing.

3. ASEAN Key Figures (2019). https://www.aseanstats.org/wp-content/uploads/2019/11/ASEAN_Key_Figures_2019.pdf

4. Balassa, B. (1966). Tariff Reductions and Trade in Manufactures among the Industrial Countries. The American Economic Review, 56(3), 466-473.

5. Bezić, H. \& Galović, T. (2013). The International Trade of OECD and EU ICT Sector. In Antončić, B. (Ed.). Proceedings of Advances in Business-Related Scientific Research Conference - ABSRC 2013 (pp. 1-2). GEA College - Faculty of Entrepreneurship.

6. Bezić, H. \& Galović, T. (2014). Machinery and Equipment Sector Trade Performance of the European OECD Member Countries. In Antončić, B. (Ed.). Proceedings of Advances in Business-Related Scientific Research Conference - ABSRC 2014. GEA College - Faculty of Entrepreneurship.

7. Bilas, V. \& Franc, S. (2009). Intraregionalna trgovina te mobilnost kapitala i rada u regionalnoj integraciji ASEAN. Zbornik Ekonomskog fakulteta u Zagrebu, 7(2), 1-20.

8. Fan, C. \& Chang, Z. (2010). The Comparative Study on International Competitiveness between China and ASEAN in Service Trade. Proceedings of the 2nd International Conference on Information Science and Engineering (pp. 6254-6258). Hangzhou.

9. De Grauwe, P. (2010). Introduction. In De Grauwe, P. (Ed.), Dimensions of Competitiveness. MIT Press. https://doi.org/10.1017/CBO9780511707964.001

10. Department of Trade and Industry (1994). Competitiveness: forging ahead. Second Competitiveness White Paper, Cmnd 2867. HMSO, London.

11. Edwards, L. \& Fagerberg, J. (2001). Benchmarking: A New and Useful Tool for Policy Learning. Working Papers on Innovation Studies No. 20010621. Centre for Technology, Innovation and Culture, University of Oslo.

12. European Council (2019). ASEAN: Council adopts conclusions. https:/www.consilium.europa.eu/en/press/press-releases/2019/01/21/council-conclusions-on-eu-asean-relations

13. EUROSTAT (2020). http://open-data.europa.eu/data/dataset/Xap3e5mUg67X0uEuF4ICIw

14. Flanagan, R., Lu, W., Shen, L. \& Jewell, C. (2007). Competitiveness in construction: A critical review of research. Construction Management and Economics, 25(9), 989-1000. https://doi.org/10.1080/01446190701258039

15. Galović, T. (2015). The international competitiveness of the pharmaceutical industry within 21 OECD countries. Ekonomski vjesnik, 28(1), 225-241.

16. Grubel, H. G. \& Lloyd, P. J. (1975). Intra-industry trade: The Theory and Measurement of International Trade in Differentiated Products. The Macmillan Press Ltd.

17. Kaldor, N. (1971). Conflicts in National Economic Objectives. Economic Journal, 81(321), 1-16. https://doi.org/10.2307/2229754

18. Krugman, P. R. (1994). Competitiveness: A Dangerous Obsession. Foreign Affairs, 73(2), 28-44. https://doi.org/10.2307/20045917

19. Lall, S. (2001). Competitiveness, Technology and Skills. Edward Elgar. https://doi.org/10.4337/9781781950555

20. Loo, M. K. L. (2018). Global competitiveness of ASEAN: Implications for Canadian businesses. Transnational Corporations Review, 10(1), 13-29. https://doi.org/10.1080/19186444.2018.1436642

21. Meiliene, E. \& Snieska, V. (2005). Lietuvos ekonominés politikos ir eksporto skatinimo strategijos saveika. Viesoji politika ir administravimas, (11), 48-54. 
22. Nababan, T. S. (2019). Development Analysis of Global Competitiveness Index of ASEAN-7 Countries and Its Relationship on Gross Domestic Product. Integrated Journal of Business and Economics, 3(1), 1-14. https://doi.org/10.33019/ijbe.v3i1.108

23. OECD (1992). Technology and the economy: The key relationships. Organization for Economic Cooperation and Development. http://oecd.org/dataoecd/33/62/2095942.pdf

24. Olczyk, M. (2016). A systematic retrieval of international competitiveness literature: a bibliometric study. Eurasian Economic Review, 6(3), 429-457. https://doi.org/10.1007/s40822-016-0054-9

25. Onyusheva, L., Thammashote, S. \& Kot, S. (2018). ASEAN: Problems of Regional Integration. Revista Espacios, 39(36), 2.

26. Porter, M. E. (2001). Strategy and the Internet. Harvard Business Review, 79(2), 62-78.

27. Porter, M. E. (1990). The Competitive Advantage of Nations. MacMillan. https://doi.org/10.1007/978-1-349-11336-1

28. Saboniene, A. (2009). Lithuanian Export Competitiveness: Comparison with other Baltic States. Inzinerine Ekonomika - Engineering Economics, 62(2), 49-57.

29. Spence, A. M. \& Hazard, H. A. (1988). International Competitiveness. Ballinger Publishing Company. https://doi.org/10.1002/tie.5060300111

30. Srivastava, D., Shah, H. \& Talha, M. (2006). Determinants of competitiveness in Indian public sector companies: An empirical study. Competitiveness Review, 16(3), 212-222. https://doi.org/10.1108/10595420610818839

31. UNCTAD (2016). Key Indicators and Trends in International Trade 2016. https://unctad.org/en/PublicationsLibrary/ditctab2016d3_en.pdf

32. Wignaraja, G. (2003). Competitiveness analysis and strategy. In Wignaraja, G. (Ed.). Competitiveness Strategy in Developing Countries (pp. 15-60). Routledge. https://doi.org/10.4324/9780203466032-9 